The Center for Global Energy, International Arbitration and Environmental Law

The University of Texas at Austin School of Law

Research Paper No. 2015-03

January 2015

\title{
The Endangered Springflow Act: How the Endangered Species Act Influences Groundwater Law and Protects Springflow in Texas
}

\section{Vanessa Puig-Williams}

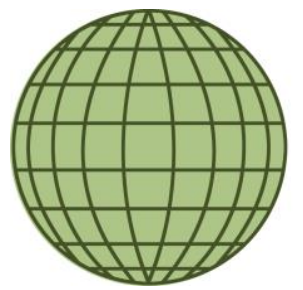

\section{ENERGY CENTER}

The Center for Global Energy,

International Arbitration and

Environmental Law

THE UNIVERSITY OF TEXAS SCHOOL OF LAW 

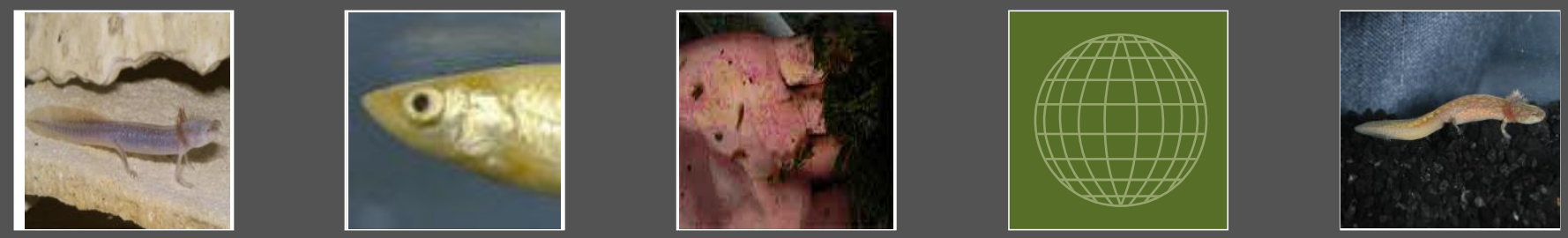

The Endangered Springflow Act: How the Endangered Species Act Influences Groundwater Law and Protects Springflow in Texas

Vanessa Puig-Williams

December 2014

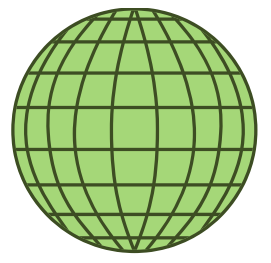

\section{ENERGY CENTER}

The Center for Global Energy, International Arbitration and Environmental Law 



\section{The Endangered Springflow Act: How the Endangered Species Act Influences Groundwater Law and Protects Springflow in Texas}

Research Paper No. 2014-03

December 2014

AUTHOR

Vanessa Puig-Williams

PRESENTED BY

Center for Global Energy, International Arbitration, and Environmental Law University of Texas School of Law 727 East Dean Keeton Street

Campus Mail Code: D1800

Austin, TX 78705

(512) 232-1408

UNDER THE DIRECTION OF

Melinda Taylor, Executive Director

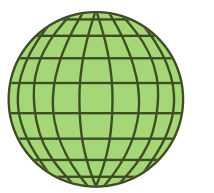

\section{ENERGY CENTER \\ The Center for Global Energy, \\ International Arbitration and \\ Environmental Law \\ THE UNIVERSITY OF TEXAS SCHOOL OF LAW}

www.utexas.edu/law/academics/centers/energy/

(C) 2014 All rights reserved 



\section{ABOUT THE ENERGY CENTER}

The Center for Global Energy, International Arbitration, and Environmental Law ("Energy Center") at the University of Texas School of Law's mission is to educate students about the law, policy, and commercial realities related to the production of energy, protection of natural resources, and the use of international arbitration to resolve commercial disputes. In addition to offering a robust course curriculum, the Center sponsors interdisciplinary research and policy analyses and provides a forum for lawyers, scientists, economists, policy makers, and stakeholders to explore solutions to the world's most pressing energy and environmental problems. The Center is engaged in research on a number of issues, including oil and gas law, the law of wind energy, incentives for renewable energy, and the policy implications of climate change for the Endangered Species Act. Beginning January 1, 2015, the Center will become the Kay Bailey Hutchison Center for Energy, Law, and Business, a new, interdisciplinary project of the School of Law and the McCombs School of Business that was approved by the University of Texas Board of Regents in May 2014.

\section{ABOUT THE AUTHOR}

Vanessa Puig-Williams is an Austin-based legal consultant with expertise in Texas environmental law. She currently practices conservation law and writes on water related issues in Texas. PuigWilliams previously practiced in the environmental division of the Texas Attorney General's Office. 


\section{Table of Contents}

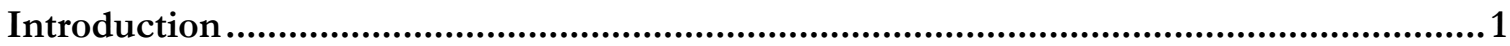

The Endangered Species Act ..................................................................................

The ESA and Springflow Protection in the Past ................................................................3

The ESA and Springflow Protection Today ...................................................................

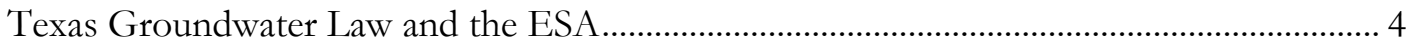

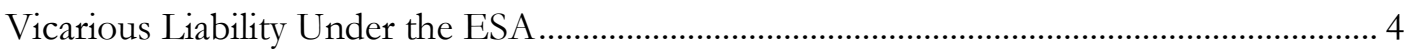

Groundwater Conservation Districts and the ESA ............................................................... 5

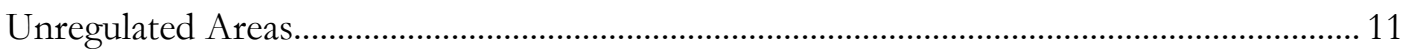

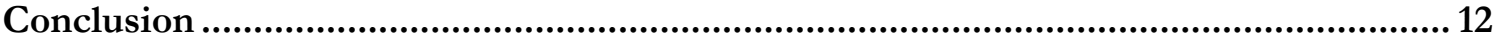




\section{Introduction}

Many springs in Texas are in danger of drying up as two contradictory forces - drought and development - collide. As groundwater from an aquifer is pumped for irrigation, municipal, or industrial use, the water level in the aquifer is lowered and the result is decreased flow from springs at the surface. The lack of recharge to the aquifer caused by drought exacerbates the decline in groundwater levels and diminished springflow. Reductions in springflow are problematic because springs sustain numerous creeks and rivers, especially during drought when surface runoff from rainfall is low. As springflow decreases, so does the flow of surface water, degrading aquatic habitats, threatening consumptive uses of water, interfering with recreational activities, and harming water quality. While the Texas State Water Plan indicates that water management strategies will focus on surface water in the future, reliance on groundwater supplies, including brackish sources, to support population growth, agriculture, and a booming oil and gas industry will continue.

In September 2011, the U.S. District Court for the District of Columbia approved a settlement agreement between the U.S. Fish and Wildlife Service (Service) and environmental groups that had filed suit against the Service for its failure to decide whether to list hundreds of species under the Endangered Species Act (ESA). The settlement agreement included a work plan, which set deadlines for the Service to decide whether or not to list over 770 specific species and designate critical habitat for them by 2018.

In April 2014, the Energy Center published a study entitled "The Conflict between Endangered Species and the State Water Plan: Will New Listings under the Endangered Species Act Thwart the State Water Planning Process?"1 In that study, we explored the potential for new ESA listings in Texas to result in delays or additional expense for new water projects included in the State Water Plan. We concluded that, with the exception of projects in the upper Brazos River where the habitat of two endangered species of minnow are located, the additional listings in Texas would be unlikely to result in clashes between the ESA's requirements and new water projects, because almost all of the Texas aquatic species on the Service's work plan are dependent on groundwater and located in areas where no new projects have been proposed.

As a result of the deadlines established in the work plan, in the last few years the Service has listed ten species in Texas that depend solely on groundwater for survival—six invertebrate species found in springs systems in West Texas and four salamanders found in central Texas springs. According to the Service, the primary threat to these species' survival is reduced springflow caused by groundwater pumping. The Service also has maintained that groundwater withdrawals from aquifers supporting springflow in spring-fed creeks of the upper Brazos River have reduced

1 | The Endangered Springflow Act | December 2014 
surface water flows, threatening the habitat of the sharpnose and smalleye shiners, two species of minnow that were recently listed as endangered.

The only entities in Texas that regulate groundwater pumping are groundwater conservation districts. In areas where the habitat of newly listed species and the boundaries of groundwater conservation districts overlap, how will the Endangered Species Act affect a district's management of its groundwater resources? In areas where groundwater conservation districts do not exist, such as Williamson County where the Georgetown and Jollyville salamanders are found, over pumping of groundwater supplies may threaten habitat. In light of the Service's recent listing decisions under the Endangered Species Act, how will the habitat of species in unregulated areas be protected?

When an endangered species is present in a spring, can the Endangered Species Act influence groundwater management and protect springflow? What regulatory tools can a groundwater conservation district utilize to protect springflow to ensure the long-term survival of rare species? What potential legal vulnerabilities do groundwater districts face if they fail to do so? What options are available under the ESA for the districts to obtain authorization for unavoidable harm to the species? In this paper, we explore the significant and developing relationship between groundwater management and endangered species protection.

\section{The Endangered Species Act}

The purpose of the Endangered Species Act is "to provide a means whereby the ecosystems upon which endangered and threatened species depend may be conserved ...."2 The law is intended to be a safety net to protect the plants and animals at greatest risk of extinction. The Endangered Species Act protects rare animals and their habitats by prohibiting the "take" of a species that has been listed as either threatened or endangered. Under the ESA, "take" means "to harass, harm, pursue, hunt, shoot, wound, kill, trap, capture, or collect, or to attempt to engage in any such conduct." 3 The Service defines "harm" to include "significant habitat modification or degradation where it actually kills or injures wildlife by significantly impairing essential behavioral patterns, including breeding, feeding, or sheltering." "The United States Supreme Court upheld this regulatory definition in Babbitt v. Sweet Home Chapter of Communities for a Great Oregon, affirming the Service's position that harm to a listed animal's habitat can constitute "take" under the ESA. ${ }^{5}$ In other words, a violation of the ESA may occur if a species' habitat is significantly modified or degraded to the point where a member of the species is killed or injured.

2 | The Endangered Springflow Act | December 2014 


\section{The ESA and Springflow Protection in the Past}

For many groundwater-dependent species, the quality of their habitat depends on consistent springflows of clean water. Increased groundwater pumping causes reductions in aquifer levels and decreased flow from springs, which in turn can degrade a species' habitat and lead to death or injury, a "take." In 1991, the Sierra Club made that argument in a lawsuit brought against the Service that has become the poster child for how "[t]he Endangered Species Act (ESA) became the instrument that eventually brought state regulation to the [Edwards] Aquifer and the end to unrestricted withdrawals of groundwater." 6

Unrestricted groundwater pumping from the Edwards Aquifer in the 1980s and early 1990s reduced springflow at San Marcos and Comal Springs, harming endangered and threatened species that depended on springflow for survival. The Sierra Club filed a lawsuit under the ESA, arguing that the Secretary of the Interior and the Service caused harm to the endangered species in Comal and San Marcos Springs by failing to ensure water levels in the Edwards Aquifer would sustain a minimum flow level from the springs necessary to protect the species. In 1993, the federal judge agreed, ordering the Service to determine minimum flow levels for the springs and threatening the State of Texas that the court would exert control over pumping in the Edwards Aquifer region if the legislature failed to act. After the judgment, the Texas Legislature responded by creating the Edwards Aquifer Authority and establishing a cap on annual withdrawals from the aquifer. The Edwards Aquifer Authority developed a regulatory program designed to protect minimum flow levels necessary for the listed species to survive. ${ }^{7}$

\section{The ESA and Springflow Protection Today}

Since this groundbreaking result in 1993, groundwater law in Texas has changed, and so has the way the Endangered Species Act influences springflow protection in Texas. The Legislature has approved the establishment of groundwater conservation districts in one hundred counties, leaving less than one-third of the state subject to an unrestricted "rule of capture."8 Moreover, in 2005, the Legislature empowered groundwater conservation districts with regulatory tools that can be used to protect springflow. ${ }^{9}$ The state law, however, does not require groundwater conservations districts to do so. Where applicable, the Endangered Species Act can be the impetus for groundwater conservation districts to utilize available regulatory tools to specifically protect springflow. Or to put it a different way, groundwater conservation districts can use the Endangered Species Act as a tool for sustainable water supply management.

3 | The Endangered Springflow Act | December 2014 


\section{Texas Groundwater Law and the ESA}

In 2005, the Legislature overhauled groundwater law in Texas and enacted the "desired future conditions process," which requires groundwater districts with jurisdiction over the same aquifers to work together in a groundwater management area to establish "desired future conditions" for these aquifers. Desired future conditions are "the desired, quantified conditions of groundwater resources (such as water levels, water quality, spring flows, or volumes) at a specified time or times in the future ...."10 According to the Texas Water Development Board, "[i]n essence, a desired future condition is a management goal that captures the philosophy and policies addressing how an aquifer will be managed" and is a way for groundwater districts to ask each other, "[w]hat do you want your aquifer to look like in the future?" 11 Under Chapter 36 of the Water Code, groundwater districts are supposed to consider "impacts on springflow" when asking this question, but the law does not require groundwater districts to enact desired future conditions that protect springflow. 12

Chapter 36 of the Texas Water Code requires groundwater conservation districts to develop management plans that address in a quantitative manner the desired future conditions for aquifers within their groundwater management area. ${ }^{13}$ Groundwater districts should be managing groundwater in such a way that the adopted desired future condition is being achieved. But nothing in the current law requires districts to specifically address springflow protection in their management plans, and as discussed above, districts must only consider impacts on springflow when adopting desired future conditions. ${ }^{14}$ The only groundwater districts, therefore, that manage groundwater to specifically protect a minimum level of springflow are those districts that have adopted desired future conditions for this specific purpose. Currently, only three groundwater conservation districts (not including the Edwards Aquifer Authority) have established desired future conditions that incorporate minimum flow levels for springs within their jurisdiction Barton Springs Edwards Aquifer Conservation District, Clearwater Underground Water Conservation District, and Kinney County Groundwater Conservation District. Although there is no mechanism in the Endangered Species Act that can force groundwater conservation districts to protect springflow, they risk the possibility of being sued for a violation of the ESA if they authorize groundwater pumping at levels that cause harm to listed species.

\section{Vicarious Liability Under the ESA}

The risk to groundwater conservation districts of being found liable for "take" under the ESA rests on a legal theory of "vicarious liability" for government agencies that authorize activities that cause harm to listed species. In Sierra Club v. Yeutter, the Fifth Circuit held that the United States Forest Service was liable for a "take" under Section 9 of the ESA because the agency's licensing practices, which permitted tree-cutting in the habitat of an endangered woodpecker, caused

4 | The Endangered Springflow Act | December 2014 
significant habitat modification resulting in a "take" of the species. Additionally, in Straban v. Coxe, the First Circuit held that the Massachusetts Division of Marine Fisheries violated Section 9 of the ESA by issuing commercial fishing licenses and permits that resulted in the "take" of an endangered whale. The Court held that a "governmental third party pursuant to whose authority an actor directly exacts a taking of an endangered species may be deemed to have violated the provisions of the ESA."15 Furthermore, the Eighth Circuit held that where an endangered species was poisoned by strychnine bait, the Environmental Protection Agency's authorization of the above ground use of strychnine pesticides and rodenticides effected a "taking" of an endangered species. ${ }^{16}$ Courts in several jurisdictions have held that governmental officials may be liable for a Section 9 "take" based on actions authorized by their regulatory activities. ${ }^{17}$

In June 2014, the Fifth Circuit held in The Aransas Project v. Shaw that the Texas Commission on Environmental Quality (TCEQ) was not liable for failing to curtail pumping from the San Antonio and Guadalupe Rivers during the drought of 2008, though reduced inflows into San Antonio Bay contributed to harm to the endangered whooping crane. ${ }^{18}$ The Court found the causal link between the TCEQ's water permitting program and the cranes' deaths too attenuated to satisfy the proximate cause requirement, citing several factors that affect crane habitat, including tides, drought and overfishing. ${ }^{19}$ The Court's decision, however, was based narrowly on the issue of proximate cause and did not reach the question of whether the state could ever be held liable for licensing third parties who cause harm to an endangered species, leaving open the possibility of vicarious liability in other cases.

\section{Groundwater Conservation Districts and the ESA}

There are two options, discussed below, open to districts that wish to inoculate themselves from Endangered Species Act liability. First, a district, working with its groundwater management area, can adopt desired future conditions and enact rules adequate to protect springflows to ensure that no takings occur. In addition, a groundwater district can seek an "incidental take permit" from the Service, which shields the district from liability associated with activities authorized by the permit, even if a take occurs.

\section{MINIMUM FLOW REQUIREMENTS}

As discussed above, a groundwater conservation district (subject to GMA approval), can adopt a desired future condition that specifically protects springflow by establishing a minimum flow level for a spring. The district can then manage groundwater by for example, curtailing permitted pumping to ensure that this desired future condition is being met.

5 | The Endangered Springflow Act | December 2014 


\section{Barton Springs}

The Barton Springs Edwards Aquifer Conservation District (BSEACD) has taken steps to protect Barton Springs, where the endangered Barton Springs salamander and the Austin Blind Salamander are found. BSEACD was established in 1987 by the Legislature for the purpose of conserving, protecting, and enhancing the Barton Springs segment of the Edwards Aquifer. ${ }^{20}$ In 1997, the Service listed the Barton Springs salamander as endangered, maintaining that reduced water quality and quantity threatened the species survival. ${ }^{21}$ In August of 2013, the Service listed the Austin Blind Salamander, which also occurs within the BSEACD's jurisdiction, as endangered. 22

Under Chapter 36 of the Water Code, BSEACD has established desired future conditions meant to "assure an adequate supply of freshwater for well users and adequate flow for endangered species" and set minimum flow levels for Barton Springs. ${ }^{23}$ BSEACD has set two desired future conditions for the Barton Springs Segment of the Edwards Aquifer. The first states, "[d]uring extreme droughts, including a recurrence of the 1950s drought of record, monthly average springflow at Barton Springs shall not be less than 6.5 cfs." 24 The second desired future condition functions as an "upper cap" on pumping and establishes that the "seven-year average springflow of Barton Springs shall not be less than 49.7 cfs during average recharge conditions." 25

To achieve the desired future conditions for Barton Springs, BSEACD has established a drought management program that requires all permit holders to implement year-round conservation measures and to curtail groundwater pumping when certain drought stages are triggered. The drought triggers are based on water levels in Lovelady Well or flow from Barton Springs. When drought is declared, BSEACD also requires permit holders to implement user drought contingency plans that incorporate conservation measures designed to further reduce groundwater pumping. BSEACD's rules are an example of how a regulatory agency can use its own authority to protect the habitat of a listed species and consequently, manage groundwater in a sustainable manner. This reduces the likelihood of a taking, thus, reducing the possibility of enforcement under the federal ESA.

\section{Salado Springs}

In February 2014, the Service listed the Salado Salamander, which lives in Salado Springs under the jurisdiction of the Clearwater Underground Water Conservation District (CUWCD), as threatened. ${ }^{26}$ The Service previously identified the Salado Salamander as a candidate species in 2002. ${ }^{27}$ In 2005, before the species was listed as threatened, CUWCD set a minimum flow level for Salado Springs of 100 acre-feet per month as a desired future condition for the Edwards (BFZ) Aquifer. ${ }^{28}$ According to CUWCD, the decision to establish a minimum flow level for Salado

6 | The Endangered Springflow Act | December 2014 
Springs was based on the "aesthetic, economic, recreational and environmental benefits that Salado Springs provides to the region." 29 To achieve the desired future condition, CUWCD measures discharge from Salado Springs and if necessary, will implement conservation measures to avoid impairment of the desired future condition. ${ }^{30}$ CUWCD's rules also provide that the district can proportionally reduce production permits in order to avoid impairment of and to achieve the desired future condition. ${ }^{31}$

With the Service's recent decision to list the Salado Salamander as threatened, despite its efforts to protect springflow, CUWCD now sits in the regulatory shadow of the Endangered Species Act. The threat of a takings claim should encourage the district to continue to protect springflow for the benefit of the species, like BSEACD has done. If the current desired future condition for Salado Springs is not adequate to protect the Salado Salamander, it can be amended. The desired future condition process is meant to be adaptive. Groundwater conservation districts are required under the law to reevaluate desired future conditions every five years taking into consideration "groundwater availability models and other data or information for the management area," 32 such as, perhaps, impacts to endangered or threatened species.

\section{HABITAT CONSERVATION PLANS}

A groundwater conservation district that has utilized available regulatory tools to protect springflow, however, may still be subject to takings claims if the tools fail to ensure that no harm to a listed species will occur. The Endangered Species Act provides another vehicle for groundwater conservation districts to use to protect springflow and shield themselves from liability under a takings lawsuit - incidental take permits. Section 10 of the ESA provides that nonfederal entities may obtain "incidental take" authorization from the Service for take associated with an activity that would otherwise be legal, but for the impact on a listed species. ${ }^{33}$ To obtain an incidental take permit, the applicant must prepare a "habitat conservation plan" (HCP) that meets certain statutory requirements, including measures that are designed to minimize and mitigate the impact to the species to the "maximum extent practicable." 34

The Service recently issued an incidental take permit to the Edwards Aquifer Authority to authorize take of the Comal and San Marcos Springs species associated with the "regulation and use of the aquifer." 35 The HCP provides several springflow protection measures. The Voluntary Irrigation Suspension Program Option (VISPO) provides financial compensation to irrigators who suspend water withdrawals when the aquifer level falls to 635 feet. The goal of another flow protection measure - the Regional Municipal Water Conservation Plan (RMWCP) - is to incentivize municipalities to conserve water so that half of all conserved water remains unpumped in the Aquifer for 15 years. According to the plan, "this means that of the 20,000 targeted acrefeet conserved, 10,000 acre-feet will remain in the Aquifer to sustain aquifer levels in support of

7| The Endangered Springflow Act | December 2014 
continued springflow." 36 Other springflow protection measures in the Edwards Aquifer HCP include 44\% reductions in groundwater permit withdrawals when Stage V drought triggers are reached and utilizing water in San Antonio Water System's aquifer storage and recovery facility to offset pumping during drought. ${ }^{37}$

The Barton Springs Edwards Aquifer Conservation District recently submitted a draft Habitat Conservation Plan to the Service as part of an Incidental Take Permit application covering certain district activities that could result in the take of the Barton Springs Salamander or the Austin Blind Salamander. The HCP incorporates numerous measures designed to protect springflow, such as improving recharge to the aquifer, encouraging permitees to find alternative sources of water, incentivizing permitees to curtail water use, reducing demand on the aquifer through conservation, and restricting groundwater pumping when springflow at Barton Springs declines to certain trigger points. ${ }^{38}$ Essentially, BSEACD's Management Plan implements the HCP, with the overall goal of protecting the species habitat and sustainably managing groundwater supply. ${ }^{39}$

The Habitat Conservation Plans developed by the Edwards Aquifer Authority and the Barton Springs Edwards Aquifer Conservation District are currently the only HCP's in Texas that cover groundwater pumping. This may change in the future. In the last two years, the Service has listed several spring dwelling species as either threatened or endangered under the Endangered Species Act. ${ }^{40}$ The Service's recent listing decisions may compel groundwater conservation districts with jurisdiction over affected springs to establish desired future conditions that incorporate minimum levels of springflow necessary to protect newly listed species and to consider applying for an incidental take permit and developing a habitat conservation plan.

\section{GROUNDWATER CONSERVATION DISTRICTS WITHOUT MINIMUM FLOW REQUIREMENTS} San Solomon and Diamond Y Springs

In July 2013, the Service listed six invertebrate species found in San Solomon and Diamond Y Springs in west Texas as endangered. ${ }^{41}$ The Service stated that a primary threat to these species is springflow decline. ${ }^{42}$ The San Solomon Springs and Diamond Y Springs are already home to several endangered species - the Comanche Springs pupfish and the Pecos gambusia, found in the San Solomon Springs, ${ }^{43}$ and the Leon Springs pupfish, Pecos gambusia, and Pecos Assiminea snail, which live in the Diamond Y Springs. ${ }^{44}$ Although Texas Parks and Wildlife and The Nature Conservancy have conserved land around these springs to protect habitat and the Service included outflow from Diamond Y Springs as critical habitat for the Leon Springs pupfish and Pecos assiminea snail, these conservation measures do not protect springflow, which can only be protected through restrictions on groundwater pumping enforced by a groundwater conservation

8 | The Endangered Springflow Act | December 2014 
district. Groundwater conservation districts in the region have not established desired future conditions that specifically protect springflow at Diamond Y and San Solomon Springs.

According to the Service, four groundwater conservations districts - Culberson County Groundwater Conservation District, Jeff Davis County Underground Water Conservation District, Presidio County Underground Water Conservation District, and the Hudspeth County Underground Water District No.1 - have jurisdiction over groundwater pumping from aquifers that could impact springflow at San Solomon Springs ${ }^{45}$ See Figure 1. Additionally, in 2013, the Legislature created the Reeves County Groundwater Conservation District. ${ }^{46}$ The geographical boundaries of Reeves County Groundwater Conservation District encompass several springs within the San Solomon Spring system. See Figure 1. For the Diamond Y Spring system, one groundwater conservation district - the Middle Pecos Groundwater Conservation District - could manage groundwater pumping to protect flows in the Diamond Y Spring system. See Figure 1. In its listing decision for the six species, the Service indicated that these groundwater districts could offer "some protection to the spring flows for these species" 47 but was critical of the districts" efforts to date, stating that there is a "lack of acknowledgement of the relationship between the groundwater resources under the Districts' management to the conservation of the springflow habitat" at both the San Solomon Spring system and the Diamond Y Spring system. ${ }^{48}$ The Service concluded that current desired future conditions established by the groundwater districts "will contribute to ongoing and future springflow declines" and are inadequate to protect against modification of habitat for the species. ${ }^{49}$

Part of the reason for the absence of desired future conditions that protect springflow in San Solomon and Diamond Y Springs is that there is ambiguity over which aquifers provide the source of water that emerges from the springs. This uncertainty about the hydrology of the springs makes it difficult for a groundwater district to know whether it is successfully managing groundwater pumping from an aquifer to meet a desired future condition established to protect springflow. It is exactly the reason the Service determined that existing regulatory mechanisms are inadequate to protect the species and opted to list the species as endangered. The Service states, "[w]ithout better understanding of the interrelationships of the aquifers and the spring flows, we cannot confidently predict whether or not the existing groundwater management for the desired future conditions will provide the necessary flows to maintain the species' habitat." ${ }^{50}$ The Service has identified a "catch 22" for groundwater districts in this region - maintaining that groundwater districts can manage groundwater to protect springflow in the region but determining that these regulatory mechanisms are inadequate to do so without further research and study related to the source of springflow for the springs. ${ }^{51}$ In the case of San Solomon and Diamond Y Springs, it is unlikely that the ESA will encourage groundwater conservation districts to establish desired future conditions that protect springflow in the near future. The uncertainty over the source water for

9| The Endangered Springflow Act | December 2014 
the springs and groundwater districts' ability to manage groundwater to protect springflow make a takings claim difficult to prove. It is obvious that hydrological research in this region is needed. At the very least, perhaps the Endangered Species Act will encourage the development of this additional science.

\section{Spring-fed Tributaries to the Upper Brazos River}

In August 2014, the Service listed the sharpnose and smalleye shiners, two species of minnows inhabiting the upper portions of the Brazos River as endangered. ${ }^{52}$ The main threat to the shiners' survival is decreasing flow in the Brazos River caused by impoundments and reductions in springflow from springs that contribute to flow in the upper Brazos River. Groundwater from the Ogallala Aquifer, which has long been used for irrigation, has resulted in decreased springflow at the headwaters of the upper Brazos. The Llano Estacado Regional Water Planning Group (Region O) is considering the pumping of brackish groundwater from the Dockum and Trinity Aquifers as a water management strategy in its Regional Water Plan. ${ }^{53}$ According to the Service, these aquifers may also contribute to surface water flow in the Upper Brazos. ${ }^{54}$ The Service is concerned that increased "groundwater withdrawal and depletion will reduce or eliminate the remaining springs and seeps of the Brazos River basin, which will lower river flow" and impact the shiners' habitat. ${ }^{55}$

The High Plains Underwater Conservation District, Garza County Underwater Conservation District, and Rolling Plains Groundwater Conservation District regulate groundwater pumping from the aquifers that underlie portions of the upper Brazos River. ${ }^{56}$ See Figure 1. Currently, the High Plains Underwater Conservation District management plan does not incorporate minimum flow levels for springs within its management area as desired future conditions for the Ogallala, Dockum, or Trinity Aquifers. Perhaps, as in west Texas, the reason for the omission is that the connection between groundwater and surface water in the upper Brazos is not well understood. Nevertheless, the Service maintains that increased groundwater pumping from the Ogallala, Dockum, and Trinity Aquifers will impact the habitat of shiners in the upper Brazos River. The Service does not articulate the role groundwater conservation districts in this region could play in protecting springflow, but its listing decision implies that without restrictions on groundwater pumping there will be "severe, detrimental impacts to surface water availability throughout Texas, including areas supporting sharpnose and smalleye shiners."

\section{San Felipe Springs and Spring-fed Pinto Creek}

San Felipe Springs in Val Verde County feeds San Felipe Creek, which is home to the Devils River Minnow. The Service listed the Devils River Minnow as threatened in 1999.58 The Devils River Minnow is also found in Pinto Creek, a spring-fed creek in neighboring Kinney County. In the 
Recovery Plan for the Devils River Minnow, the Service states, "increases of water withdrawals from aquifers that support spring flows in the range of the Devils River minnow...could result in reduction of critical spring flows or the drying of streams that support the species." 59

The Kinney County Groundwater Conservation District has adopted desired future conditions that establish minimum flow levels for Los Moras Springs. ${ }^{60}$ Los Moras Springs feeds Los Moras Creek, where the Devils River Minnow once lived but now is extirpated. Although Kinney County Groundwater Conservation District monitors groundwater levels and spring flow in Pinto Creek, ${ }^{61}$ the District has not adopted desired future conditions that establish minimum flow levels for Pinto Creek.

\section{Unregulated Areas}

Currently, there is no groundwater conservation district in Val Verde County that can restrict pumping to protect the Devils River Minnow's habitat in San Felipe Creek. Proposals by a water supply corporation to pump groundwater from the Edwards-Trinity Aquifer in Val Verde County to the Permian Basin, where a booming natural gas industry is prompting the demand for an additional water supply, has many locals and environmental advocates concerned about the impact large scale groundwater withdrawals from the Edwards-Trinity Aquifer will have on the habitat of the Devils River Minnow. ${ }^{62}$

In the Recovery Plan for the Devils River Minnow, the Service states that "delisting the Devils River Minnow should be considered when "[a]dequate flows in streams supporting Devils River minnow have been assured...through State or local groundwater management plans . . .."63 Without a groundwater district in Val Verde County, there is no mechanism in place to ensure adequate springflow in San Felipe Creek. As a result of local concern over groundwater resources, it is likely that legislation will be introduced next session creating a groundwater conservation district in Val Verde County.

In addition, next year the Service will issue a listing decision for the Texas Hornshell, a species of mussel found in the Devils River. Large groundwater withdrawals from the Edwards-Trinity Aquifer may also impact flows to the Devils River and the habitat of the Texas Hornshell. To protect flow for the Devils River Minnow and possibly the Texas Hornshell, a new groundwater conservation district in Val Verde County could utilize the desired future condition process to establish minimum flow requirements for springs supporting endangered species habitat.

In areas of the state without a groundwater conservation district, such as northern Travis County and Williamson County, there is no mechanism to protect springflow. The groundwater conservation districts in Groundwater Management Area 8 adopted desired future conditions that

11 | The Endangered Springflow Act | December 2014 
maintain minimum flows for aggregated springs and streams in this unregulated area of the Edwards (Balcones Fault Zone) Aquifer. But these desired future conditions are impossible to achieve without a groundwater conservation district managing groundwater withdrawals in these specific areas. Without a groundwater district, restrictions cannot be placed on pumping in the area, which is experiencing rapid population growth.

The Service recently listed the Georgetown Salamander, which is found in Williamson County, and the Jollyville Plateau Salamander, found in Northern Travis County and Williamson County as threatened. ${ }^{64}$ Theoretically, pumpers in these unregulated areas are vulnerable to an enforcement action under the ESA if a plaintiff can show that groundwater withdrawals contributed to a reduction in springflow and resulted in a take of a listed species. It is difficult to predict how the Endangered Species Act can influence springflow protection in regions without a groundwater conservation district, but at the very least, perhaps, the Act's contribution will be to encourage the creation of one.

\section{Conclusion}

While the Endangered Species Act may not always result in the immediate adoption of desired future conditions that protect springflow, especially where a groundwater conservation district does not exist or in areas where the hydrology is still a mystery, its regulatory shadow looms. For springs where the hydrological connection is understood, groundwater conservation districts can use the Endangered Species Act as a tool for sustainable water supply management. Depending on how one looks at it, the Endangered Species Act can be either the carrot or the stick prompting groundwater conservation districts that preside over springs containing listed species to develop desired future conditions that protect springflow and ensuring that springflow protections remain in the future. 
FIGURE 1. GROUNDWATER CONSERVATION DISTRICTS AND ENDANGERED/THREATENED SPECIES THAT DEPEND ON SPRINGFLOW FOR HABITAT

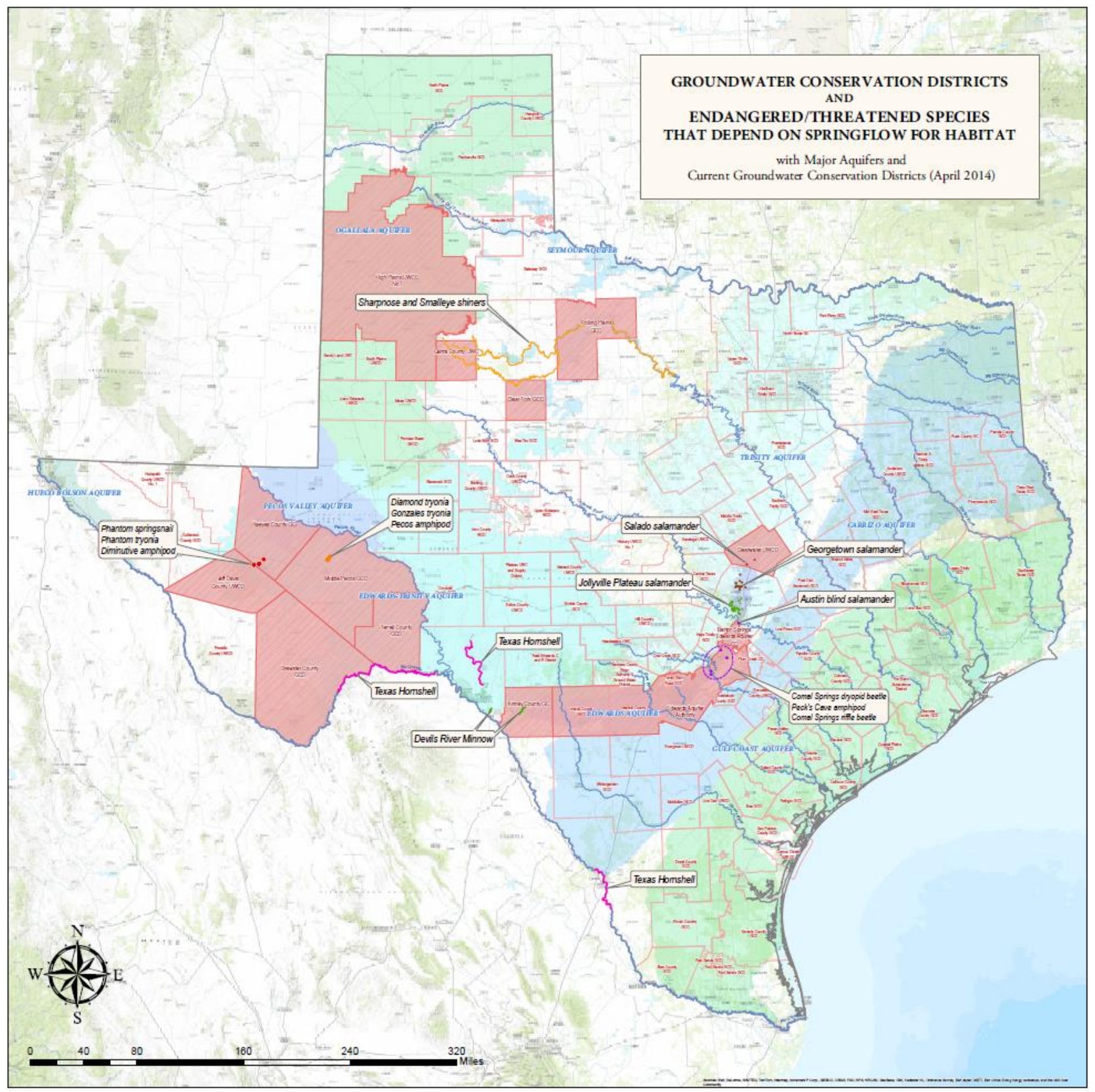

MAP CREDIT: LAURA EVANS, NATHANIEL BYARS, AND ARTHUR REYNA, III.

To see a high-resolution, large-format version of the map in Figure 1, visit http://tinyurl.com/k2x9z3z. 
TABLE 1: SPRINGS WITH LISTED SPECIES AND/OR MINIMUM FLOW REQUIREMENTS

\begin{tabular}{|c|c|c|c|}
\hline SPRING & $\begin{array}{l}\text { GROUNDWATER } \\
\text { CONSERVATION } \\
\text { DITRICT (GCD) }\end{array}$ & $\begin{array}{l}\text { DESIRED FUTURE CONDITION (DFC) WITH } \\
\text { MINIMUM FLOW LEVEL (MFL) FOR SPRINGS }\end{array}$ & ESA LISTING \\
\hline $\begin{array}{l}\text { Barton } \\
\text { Springs }\end{array}$ & $\begin{array}{l}\text { Barton Springs } \\
\text { Edwards Aquifer GCD }\end{array}$ & $\begin{array}{l}\text { During extreme drought, monthly average } \\
\text { springflow at Barton Springs shall not be } \\
\text { less than } 6.5 \mathrm{cfs} \text {. } \\
\text { Seven-year average springflow of Barton } \\
\text { Springs shall not be less than } 49.7 \mathrm{cfs} \\
\text { during average recharge conditions. }\end{array}$ & $\begin{array}{l}\text { Barton Springs } \\
\text { Salamander, Austin } \\
\text { Blind Salamander }\end{array}$ \\
\hline $\begin{array}{l}\text { Salado } \\
\text { Springs }\end{array}$ & $\begin{array}{l}\text { Clearwater } \\
\text { Underground Water } \\
\text { Conservation District }\end{array}$ & $\begin{array}{l}\text { The desired future condition of the } \\
\text { Edwards (BFZ) aquifer is based on } \\
\text { maintaining Salado Spring discharge into } \\
\text { Salado Creek during a repeat of } \\
\text { conditions similar to the 1950's drought of } \\
\text { record. Under the drought of record } \\
\text { conditions, a spring discharge of } 200 \text { acre- } \\
\text { feet per month is preferred and } 100 \\
\text { acre-feet per month is the minimum } \\
\text { acceptable spring flow }\end{array}$ & Salado Salamander \\
\hline $\begin{array}{l}\text { San Solomon } \\
\text { Springs }\end{array}$ & $\begin{array}{l}\text { Culberson County } \\
\text { GCD, Jeff Davis } \\
\text { County Underground } \\
\text { Water Conservation } \\
\text { District, Presidio } \\
\text { County Underground } \\
\text { Water Conservation } \\
\text { District, and the } \\
\text { Hudspeth County } \\
\text { Underground Water } \\
\text { District No.1, Reeves } \\
\text { County GCD }\end{array}$ & None & $\begin{array}{l}\text { Amphipod } \\
\text { Diminutive, } \\
\text { Phantom } \\
\text { Springsnail, and } \\
\text { Phantom Tryonia } \\
\text { snail }\end{array}$ \\
\hline $\begin{array}{l}\text { Diamond } Y \\
\text { Springs }\end{array}$ & Middle Pecos GCD & None & $\begin{array}{l}\text { The Pecos } \\
\text { Amphipod, Gonzales } \\
\text { Springsnail, and } \\
\text { Diamond Tryonia } \\
\text { snail }\end{array}$ \\
\hline $\begin{array}{l}\text { Spring-fed } \\
\text { Upper Brazos }\end{array}$ & High Plains GCD & None & $\begin{array}{l}\text { Sharpnose and } \\
\text { Smalleye Shiners }\end{array}$ \\
\hline $\begin{array}{l}\text { San Felipe } \\
\text { Springs/ } \\
\text { Creek }\end{array}$ & None & None & Devils River Minnow \\
\hline $\begin{array}{l}\text { Spring-fed } \\
\text { Pinto Creek }\end{array}$ & Kinney County GCD & None & Devils River Minnow \\
\hline
\end{tabular}




\section{- Endnotes -}

1 See https://www.utexas.edu/law/centers/energy/wp/wp-content/uploads/centers/energy/ESA-and-Planning-4-9-2014MP-5-36-PM-1.pdf (viewed on October 4, 2014).

216 U.S.C. $\int 1531(b)$.

316 U.S.C. $\int 1538$.

450 C.F.R. $\$ 17.3$ (2012).

5515 U.S. 687 (1995).

${ }^{6}$ Todd H. Votteler, The Little Fish that Roared: The Endangered Species Act, State Groundwater Law, and Private Property Rights Collide Over the Texas Edwards Aquifer, 28 Envtl. L. 845, Winter (1998).

7 Sierra Club v. Lujan, No. MO-91-CA-69, 1993 WL 151353 (W.D. Tex. Feb.1, 1993); See Todd H. Votteler, Ph.D. and Robert L. Gulley, PH.D, The Edwards Aquifer Habitat Conservation Plan, The Water Report, Issue 124 (June 15, 2014).

${ }^{8}$ See Sipriano v. Great Springs Waters of America, Inc. 1. S.W.3d at 76 (Tex. 1999)

${ }^{9}$ Act of May 24, 2005 79 th Leg. R.S., ch. 970 (H.B. 1763), 2005 Tex. Gen. Laws 3247 (codified as amendments to Tex. Water Code. ch. 36).

10 31Tex. Admin. Code \$356.2(8).

${ }^{11}$ Robert E. Mace, et. al. A Street Car Named Desired Future Conditions, The Changing Face of Water Rights in Texas (2008).

12 Tex. Water Code $\$ 36.108$ (d)(4).

13 Tex. Water Code S 36.1071(a).

${ }^{14}$ Tex. Water Code $\int 36.108(\mathrm{~d})(4)$.

15 Strahan v. Coxe, 127 F.3d 155, 163 (1st Cir. 1997)

${ }^{16}$ Defenders of Wildlife v. Adm'r, E.P.A., 882 F.2d 1294 (8th Cir. 1989).

17 See Animal Welfare Inst. v. Martin, 623 F.3d 19, 25-26 (1st Cir. 2010) (state); Loggerhead Turtle v. Cty. Council of Volusia Cty., 148 F.3d 1231, 1249 (11th Cir. 1998) (county); Animal Welfare Inst. v. Martin, 588 F. Supp. 2d 70, 99-100 (D. Me. 2008) (state); United States v. Town of Plymouth, 6 F. Supp. 2d 81, 92 (D. Mass. 1998) (city); Animal Prot. Inst. v. Holsten, 541 F. Supp. 2d 1073, 1078-79 (D. Minn. 2008) (state); Seattle Audubon Soc'y v. Sutherland, 2007 WL 1300964, *25 (W.D. Wash. May 2, 2007) (state).

18 Aransas Project v. Shaw, 756 F.3d 801 (5th Cir. 2014).

${ }^{19} I d$. at 821.

${ }^{20}$ Barton Springs Edwards Aquifer Conservation District (BSEACD) Management Plan at 6 (2013) [hereinafter BSEACD Management Plant] available at http://www.bseacd.org/uploads/Financials/MP FINAL TWDBapproved 1 72013 Body.pdf (viewed on October 4, 2014).

2162 Fed. Reg. 23377 at 23384 (April 30, 1997). 


\section{- Endnotes Continued -}

2278 Fed. Reg. 51,278 (August 20, 2013).

23 See Desired Future Conditions for the Barton Springs Segment of the Edwards Aquifer, available at http://www.bseacd.org/uploads/Financials/desired future conditions for District Aquifers Adopted.pdf (viewed on October 4, 2014).

${ }^{24}$ BSEACD Management Plan at 9.

${ }^{25} \mathrm{Id}$.

2679 Fed. Reg. 10,235 (final rule February 24, 2014).

2767 Fed. Reg. 40660 (June 13, 2002).

${ }^{28}$ Clearwater Underground Water Conservation District, Management Plan at 8 (February 8, 2011) [hereinafter CUWCD Management Plan] available at http://www.cuwcd.org/pdf/CUWCD-District\%20Management \%20Plan.pdf (viewed on October 4, 2014).

${ }^{29}$ Email from Mike Gershon, General Counsel, Clearwater Underground Water Conservation District (September 17, 2014) (on file with author).

${ }^{30}$ CUWCD Management Plan at 25.

${ }^{31}$ Clearwater Underground Water Conservation District, District Rules, Rule 9.2 at 37 (February 1, 2014).

32 Tex. Water Code $\int 36.108(d)$.

33 16 U.S.C. $₫ 1539$.

3416 U.S.C. $\$ 1539(a)(1)(B)$.

35 Recon Environmental, et al., Edwards Aquifer Recovery Implementation Program Habitat Conservation Plan (November 2012), available at http://www.eahcp.org/files/uploads/Final $\% 20 H C P \% 20$ November $\% 202012$.pdf (viewed on October 4, 2014).

36 See Edwards Aquifer Habitat Conservation Plan, Flow Protection Measures available at http://www.eahcp.org/index.php/flow protection/ (viewed on October 4, 2014).

${ }^{37} I d$.

38 BSEACD Proposed Habitat Conservation Plan, Table 6-1, at 136 (September 2014) available at http://www.bseacd.org/uploads/HCP/DraftHCP_20140829.pdf

${ }^{39}$ See HCP Overview available at http://www.bseacd.org/projects/habitat-conservation-plan/hcp-overview/\#goal

${ }^{40} I d$.

.41 78 Fed. Reg. 41,227 (July 9, 2013). The Pecos Amphipod (a freshwater crustacean), the Gonzales Springsnail, and Diamond Tryonia snail live in the Diamond Y Spring System. The Amphipod Diminutive (a freshwater crustacean), the Phantom Springsnail, and Phantom Tryonia snail are located in the San Solomon Spring System.

${ }^{42}$ Id. at $41,239-41243,41,248-41,251$.

4332 Fed. Reg. 4001 (March 10, 1967) Final Rule Listing the Comanche Springs Pupfish as Endangered; 35 Fed. Reg. 13519 (October 12,1970) Final Rule Listing Pecos Gambusia as Endangered. 


\section{- Endnotes Continued -}

4445 Fed. Reg. 54678 (August 15, 1980), Final Rule Listing the Leon Springs Pupfish as Endangered; 35 Fed. Reg. 13519

(October 12,1970) Listing Pecos Gambusia as Endangered.

4578 Fed. Reg. 41,227 at 41,245 (July 9, 2013).

46 Act of May 17, 2013, 83 ${ }^{\text {rd }}$ Leg. R.S. (S.B. 890) available at

http://www.legis.state.tx.us/tlodocs/83R/billtext/pdf/SB00890F.pdf (viewed on October 4, 2014).

4778 Fed. Reg. 41,227 (July 9, 2013) at 41,245, 41,252.

${ }^{48} I d$. at 41,249 .

${ }^{49} I d$. at 41246.

${ }^{50} I d$. at 41253.

${ }^{51} I d$. at $41245,41252$.

5279 Fed. Reg. 45273 (August 4, 2014).

${ }^{53}$ Llano Estacado Region-Region 0 Regional Water Plan at 4-232 (2011).

${ }^{54}$ Draft Species Status Assessment Report for the Sharpnose Shiner and Smalleye Shiner at 49 (U.S. Fish and Wildlife Service June 28, 2013) (citing Baldys III S and Schalla FE. 2011. Base flow (1966-2009) and streamflow grain and loss (2010) of the Brazos River from New Mexico-Texas state line to Waco, Texas, USGS Scientific Investigations Report 2011-5224 at 34-35) [hereinafter SSA] available at http://www.regulations.gov/\#!documentDetail;D=FWS-R2-ES-2013-0083-0002 (viewed on October 4, 2014).

${ }^{55}$ SSA at iii.

${ }^{56}$ See High Plains Underground Water Conservation District Management Plan, Section 3-Groundwater Resources, 2014 2024, available at

http://static.squarespace.com/static/53286fe5e4b0bbf6a4535d75/t/53f65273e4b0f015bbd664b0/1408651891658/HPWD \%20Management $\% 20 \mathrm{Plan} \% 208.21 .14 . \mathrm{pdf}$ (viewed on October 10, 2014).

${ }^{57} \mathrm{SSA}$ at 50.

5864 Fed. Reg. 56596 (October 20, 1999).

${ }^{59}$ U.S. Fish and Wildlife Service Recovery Plan for the Devils River Minnow at 1.7-3 (September 2005) available at http://www.fws.gov/southwest/es/Documents/R2ES/Devils River Minnow FINAL Recovery Plan.pdf (viewed on October 20, 2014).

${ }^{60}$ Kinney County Groundwater Conservation District Management Plan at 9 (2013) available at http://www.twdb.state.tx.us/groundwater/docs/GCD/kincgcd/kincgcd mgmt plan2013.pdf (viewed on October 20, 2014).

${ }^{61} I d$. at 14.

62 See Alana Rocha, Small Towns Wrestle With Lengths They'll Go for Water, The Texas Tribune (October 5, 2014) available at https://www.texastribune.org/2014/10/05/small-towns-wrestle-lengths-theyll-go-water/ (viewed on October 4, 2014).

${ }^{63}$ U.S. Fish and Wildlife Service Recovery Plan for the Devils River Minnow, Executive Summary at iv (September 2005) available at http:/ / ecos.fws.gov/docs/recovery_plan/050913.pdf (viewed on November 11, 2014).

6479 Fed. Reg. 10,235 (final rule February 24, 2014). 